\title{
The impact of human activities in the Gutâiului Mountains, Romania
}

\section{Angelica FEURDEAN ${ }^{*}$ \& Ciprian ASTALOŞ²}

\author{
${ }^{1}$ Western University "Vasile Goldiş", Mihai Viteazu 26, 440030, Satu Mare, Romania \& Quaternary Research Group, Department of \\ Geology, "Babeş-Bolyai" University, Kogălniceanu 1, 400084 Cluj-Napoca, Romania \\ ${ }^{2}$ Satu Mare County Museum, Vasile Lucaciu str. 21, 440031 Satu Mare, Romania
}

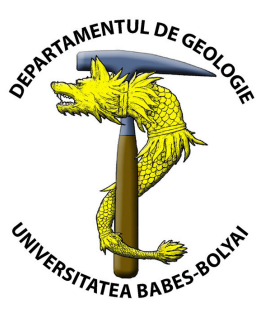

\begin{abstract}
The examination of pollen and charcoal from the Gutâiului Mountains in northwestern Romania and the archaeological evidence from surroundings provides some information on how past human activities have changed the vegetation in this region. The first evidence of potential human influence upon the woodlands is manifested by fire clearance recorded at approximately 7900 cal. yr BP coinciding with the Early Neolithic. The charcoal peaks at ca. 5750, 3300, 2700, 1500, 1000 cal. yr BP, and during the last 300 years are associated with episodes of decline of main woodland constituents (Ulmus, Tilia, Fraxinus, and Corylus), and the expansion of fire-precursors (Betula, Alnus, and Corylus), and of herb species that indicate an anthropogenic disturbance. The small openings created within the woodlands were probably used as grazing areas. The first signs of agriculture appear at ca. $1500 \mathrm{cal}$. yr BP. Only during the last 300 years does pollen of the cereals e.g. Secale, Hordeumgroup, Poaceae $>40 \mu \mathrm{m}$, suggest the spread of arable field in the lowlands (Oaş Depression), but not in the proximity of the study basins.
\end{abstract}

Key words: human impact, pollen, charcoal, fire history, Gutâiului Mountains, Oaş Depression, Romania

\section{INTRODUCTION}

With increasing pressure of our environment as a result of climatic change and anthropogenic impact, research focusing on understanding the complexity of humanclimate-environmental interaction is crucial. The palaeoecological studies from central-eastern and southeastern Europe indicate that humans started to shape the landscape approximately 7000 years ago, and intensified during the last 4000 years. Human activities were complex and marked by changes in the forest composition due to deforestation, forest grazing, extension of pasturelands, and agriculture (Behre, 1988; Ammann, 1989; Willis, 1994, 1997; Willis and Bennett, 1994; Willis et al., 1998; Rösch, 1998; Gardner, 2002; Andriç and Willis, 2003; RalskaJasiewiczowa et al., 2003; Sümegi, 2004). The climate has influenced both natural vegetation and human activities. Therefore, in periods with favorable climatic conditions (warmer and drier) agriculture has extended. During less favorable environmental conditions these fields were abandoned and forest re-expanded (Berglund, 2003).

Palaeoecology has several ways to identify human influence upon the vegetation. Pollen and plant macrofossil analyses are the methods most frequently used to recognize these changes (Iversen 1949, 1960; Behre, 1981, 1988; Ammann, 1989; Berglund, 2000; Birks, 2003). Anthropogenic disturbance of the vegetation can be traced by the following parameters: the change in tree pollen types and their abundance, the record of pollen of cereals and other crops, weeds, ruderal plants, and an increasing in pollen values of pastures and meadows species. Caution, however, is required for pollen analysis. Many pollen taxa related to anthropogenic activities cannot be identified at species level and many of these pollen types are deposited close to their place of origin. Therefore, the amount of crops tends to be underrepresented. Model of pollen dispersal have shown that small sites provide local vegetation reconstruction (up to several kilometers distance), whereas larger sites provide a regional signal (Jacobson and Bradshaw, 1981; Bradshaw, 1991; Sugita, 1994). The analysis of charcoal particles provides another method that may give insights about the human-induced burning for clearance of the forest (Clark, 1988; Whitlock and Larson, 2001). The quantity of the charcoal is influenced by several factors such as: the type of material burnt, the intensity of the fire, duration, temperature and basin size (Clark, 1988; Whitlock and Larson, 2001). It was also demonstrated that the fire and thus the charcoal particles increase under drier and warmer climatic conditions (Patterson et al., 1987). Furthermore, dispersal of charcoal particles depends of the size of the particles, the smaller the particles (microscopic charcoal under $100 \mu \mathrm{m}$ ) the more far away they are transported (up to several hundreds kilometers) (Whitlock and Larson, 2001).

To test the source of fires (natural or anthropogenic fires) different basin sizes need to be analyzed. The climatically driven fires should be observed at a regional scale and replicated in different sites. Human induced fires, however, should occur locally and at a smaller scale. With all the drawbacks, pollen and charcoal analysis, nevertheless, represent powerful techniques to reveal the past fires and their impact on the vegetation. 
In the study area (northwestern Romania) basic palaeoecological observations about human influence on vegetation has been previously made by Lupşa (1980). Several archaeological finds are available from the Oaş Depression (Bitiri, 1972; Bader, 1978; Maxim, 1999; Németi \& Astaloş, 2001; Marta, 2001), but up to date no archaeological records exist in the proximity of the study sites. None of these early pollen diagrams, nor the archaeological sites have independent chronology. Recent work in the Gutâiului Mountains, however, allowed detailed insights about vegetation and climate history from the Last Glacial Maximum up to the present (Feurdean et al., 2001; Wohlfarth et al., 2001; Björkman et al., 2002, 2003; Feurdean, 2004, 2005a, b; Feurdean \& Bennike, 2004).

This paper presents an overview of the pollen diagrams (Preluca Tiganului and Steregoiu) from the Gutâiului Mountains in order to reveal when and how the human activities have modified the woodlands. In addition, this paper presents micro-charcoal results of Steregoiu sequence that can support the human interpretation of vegetation changes. This is the first work in the region that links the vegetation records to the archaeological evidences from lowland areas (Oaş Depression and surroundings) in order to reveal the relationship between human and vegetation.

\section{THE STUDY AREA}

The study sites Preluca Tiganului (1 ha, $730 \mathrm{~m}$ a.s.1.) and Steregoiu (0,5 ha, $790 \mathrm{~m}$ a.s.1.) are two overgrown crater lakes situated on the western flank of the Gutâiului Mountains. This massif is part of the Eastern Carpathians mountain chain and has a rather low elevation with peaks attaining maximum elevation of $1400 \mathrm{~m}$. a.s.l. (Fig. 1). The beech (Fagus sylvatica) forest, with some Carpinus betulus, Picea abies, and Corylus avellana, covers the slopes near these basins (Istvan et al., 1990). The Oaş Depression (Fig. 1) is situated west of the Gutâiului Mountains, in the lowland and has a surface of $614 \mathrm{~km}^{2}$ (Velcea, 1964), whereas the Someş Valley is located south and south-west of the Gutâiului Mountains (Fig. 1).

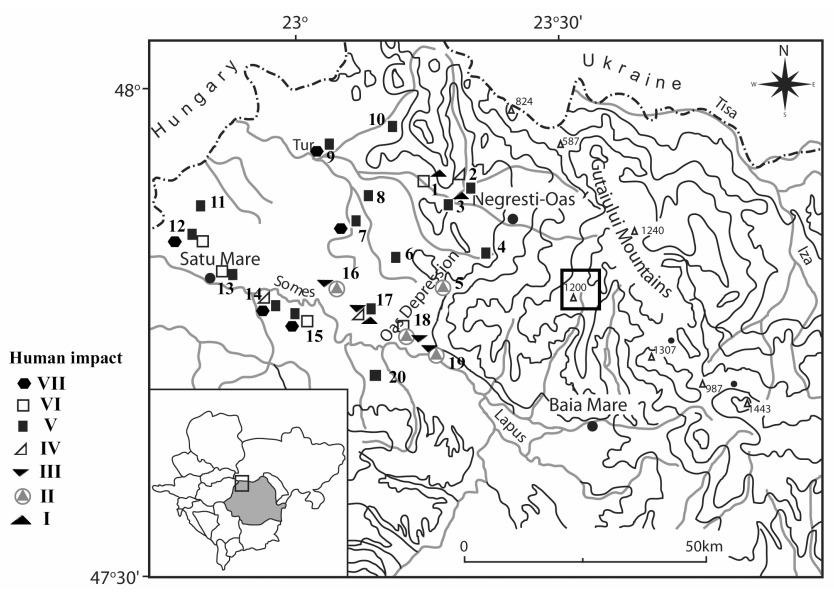

Fig. 1. Map showing the location of the study area in the Gutaiului Mountains and the archaeological sites from the Oaş Depression and Someş Valley presented in text and Tabel 1.

1. Călineşti Oaş, 2. Boineşti, 3. Remetea Oaşului, 4. Vama,

5. Oraşu Nou, 6. Iojib, 7. Livada, 8. Adrian, 9. Turulung Vii,

10. Turț, 11. Noroieni, 12. Lazuri, 13. Odoreu, 14. Culciu Mic, 15. Culciu Mare, 16. Dumbrava, 17. Medieşu Aurit, 18. Apa, 19. Seini, 20. Valea Vinului.

\section{MATERIAL AND METHODS}

The methodology for pollen, charcoal, lithology and radiocarbon analyses used in this study were presented in detail by Björkman et al. (2002), Feurdean (2004, 2005). At the Steregoiu study site, pollen analysis was carried out at 2$\mathrm{cm}$ intervals. Micro-charcoal particles were counted on each second pollen slide, i.e. every $4^{\text {th }} \mathrm{cm}$. At the Preluca Tiganului site the resolution varied between $2.5-4 \mathrm{~cm}$. Lycopodium tablets with a known number of spores were added to each sample to determine total fossil pollen and charcoal concentrations (Stockmarr, 1971). Percentages of terrestrial pollen were calculated on the basis of their total sum, excluding spores and pollen of aquatics. Percentages of spores and aquatic pollen types were calculated on the basis of the total sum including terrestrial, spores and aquatic pollen types. An average of at least 500 pollen grains, excluding aquatics and spores, were counted at each level. The pollen diagrams were drawn using TILIA and TILIA Graph (Grimm, 1992).

The chronology is based on 5 AMS radiocarbon dates at Preluca Tiganului and 14 at Steregoiu performed on terrestrial plant macrofossils and/or on peat.

The AMS radiocarbon ages were converted into calibrated years BP using the calibration curve of Stuiver et al., 1998 (INTCAL 98) and the OxCal v.3.5 program (Bronk Ramsey, 1995). The dates used to construct a chronology for the pollen diagram is the mid-point of the calibrated interval (at $\pm 2 \sigma$ ) or an adjusted date which takes into account the calibration curve and the most probable interval (at $\pm 2 \sigma$ ), and the stratigraphic position of the samples (Björkman et al., 2003).

The archaeological data was taken from published archaeological sites from the Oaş Depression (Fig.1). Also included in this study are some other archaeological records obtained from sites situated along the Someş plain (Fig. 1).

\section{RESULTS AND DISCUSSION}

Both sediment sequences cover the time period from the end of the Last Glacial Maximum to the present day (Wohlfarth et al., 2001; Björkman et al., 2002, 2003; Feurdean, 2004, 2005a,b; Feurdean and Bennike, 2004). Coniferous (Pinus, Picea, and Larix), and cold-tolerant deciduous trees (Betula, Populus, Salix, and Alnus) have occurred during the Lateglacial. At the onset of the postglacial deciduous woodlands dominated by Ulmus, were followed at ca. 10,700 cal. yr BP by the expansion of closed woodlands including Quercus, Tilia, and Fraxinus, and at ca. 10,300 cal. yr BP of Corylus. From ca. 8000 cal. yr BP onwards, the pollen and charcoal record associated with archaeological evidence indicate some anthropogenic disturbance on the vegetation in the Gutâiului Mountains and the Oaş Depression.

Four types of changes in the pollen and charcoal diagrams from the Gutâiului Mountains were used to obtain information about human activities upon these vegetation: (1) change in forest composition and density;

(2) increase in charcoal concentration;

(3) increase in herbaceous plant indicators of pastures and meadows, and

(4) appearance of pollen of cultivated plants. 


\section{Changes in woodland composition and density and forest fires}

The first indicator of anthropogenic influence on the vegetation is the reduction of woodland density. This can be traced by a decline in arboreal pollen (AP) along with an increase in non-arboreal pollen (NAP). Furthermore, change in woodland composition (e.g. the replacement of the main forest constituents by early succcessional plants such as Betula, Alnus, Corylus, Fraxinus, and Pinus) is also a good marker of anthropogenic disturbance. These alternations of the woodland structure can be a consequence of selective forest clearance (e.g. for fuel, material for constructions, etc) or the burning of woodland to obtain agricultural or pastoral fields. In both cases, the regeneration of the forest is usually made with opportunistic species such as those mentioned above. It is well documented that early humans utilised fire to manipulate the vegetation and to preserve the openness in the woodlands (Birks, 2003).

Anthropogenic indicators before $1500 \mathrm{cal}$. yr BP are rare in the Gutâiului Mountains. Changes are first indicated, however, around 7500-7900 cal. yr BP, when Betula and Fraxinus re-expanded slightly, coinciding with low, but steady occurrence of pollen grains of Carpinus and Fagus (Figs. 2, 3). Climatic conditions could have determined the forest changes as suggested by Björkman et al. (2003) and Feurdean (2004, 2005a). Increased fire activity between $7800-7900$ cal. yr BP is shown by the rise in micro-charcoal concentration at Steregoiu (Fig. 4). This is followed by a small increase of pollen grains of ruderal and plant indicators of pasturelands and meadows (Plantago lanceolata, Artemisia, Rumex acetosa/acetosella, Sinapistype, and Rosaceae). Considering the positive correlation between micro-charcoal concentration, the expansion of fire-favored tree species, and herb of anthropogenic indicators, these modifications could be the consequence of anthropogenical-induced burning (Human impact I, Table 1). Thus, the first grazing areas emerged in the recent burnt habitats within a forested environment. In burnt, unused areas, Betula and Fraxinus were likely established.

Although no archaeological sites have been discovered in the Gutâiului Mountains, there is at least one in the Oaş Depression (Németi and Astaloş, 2001) and a few others in northwestern Romania (Maxim, 1999). There are archaeological evidence for settlements in neighboring areas such as north-eastern Hungary (Horvath and Hertelendi, 1994), and Transcarpathian Ukraine (Potushniak, 2004). These finds belong to the Early Neolithic age (the final phases of the Starčevo-Körös/Criş culture) and yield an age of 7500-7650 cal. yr BP. Some other isolated tools considered of the Neolithic Age were also reported from the Oaş Depression and Someş Valley (Maxim, 1999). Giving the favorable condition in the Oaş Depression, the early Neolithic tribes most likely established settlements along small rivers in this area. They had cultivated crops, but hunting, fishing and gathering could also have been practised (Ursulescu et al., 2001; Sümegy, 2004). However, taking into consideration the short distance from the archaeological sites in the Oaş Depression and our palaeoecological sites, the Early Neolithic tribes also may have used the mountains resources for several economical and technological activities (e.g. hunting, collecting rocks, wood for pottery confection, constructions, fuel, etc). Their impact upon the woodlands in the Gutâiului Mountains seems, however, minimal. In north-eastern Hungary, alongside archaeological evidence, the palaeoecological data have also revealed the anthropogenic influence upon the vegetation already at ca. 9000 cal. yr BP (Willis, 1997).

A new variation in vegetation composition is clearly seen between 6000-6600 cal. yr BP at Preluca Tiganului (Fig. 3). The vegetational modifications are represented by a distinct peak in Fagus pollen values, increasing percentages for Betula, Corylus, and Salix and of herbs such as Artemisia, Rosaceae, Urtica, and Asteraceae. Archaeological sites of the Late Neolithic (Tisa and Herpály cultures) and Early Cooper Age (Tiszapolgár culture) have been found in the Someş Valley and north-eastern Hungary (Maxim, 1999; Willis et al., 1998; Iercoşan, 2002). Some woodland clearances may have occurred here during this framework, and possible in the Gutâiului Mountains, and in the created openings the above-mentioned taxa could have established (Human impact II, Table 1).

A few changes in the composition of the pollen assemblages are recorded between 5000-5750 cal. yr BP, during the time of Carpinus establishment and expansion. At Preluca Tiganului, this is represented by a slight decline in pollen values of Quercus, Ulmus, Tilia, and Fraxinus, coincidently with increasing values for Betula, Alnus, and Corylus (Fig. 3). High percentage spores of Polypodiaceae undiff., and some pollen of herbs is also observed. A hiatus occurred at Steregoiu making difficult to establish the age of Carpinus expansion (Fig. 2). However, it is assumed to have occurred synchronously with the neighbouring sequence (Feurdean, 2005). Both underlying climatic and human impact causes may have triggered this vegetational change. The small rise in micro-charcoal particles could be the result of natural forest fires under drier climatic conditions or antropogenically induced burning for management of the vegetation (Fig. 4). Low peat accumulation rates, high values of total pollen concentration, and the reduction of wetland indicators associated with ecological requirements of Carpinus (warmer summer and winter temperatures) are evidence for drier climate conditions (Feurdean, 2004, 2005). Woodland clearances and human-induced burning are, however, not excluded (Human impact III, Table 1). In the habitats with greater amount of light Carpinus, Corlyus, ferns, and herbs probably established.

From archaeological point of view, this time period coincides with the final part of the Early Cooper Age (Tiszapolgár), the Middle Cooper Age (Bodrogkeresztúr), and the Late Cooper Age (Baden and Coțofeni cultures) (Willis et al., 1998; Ciugudean, 2000; Sümegy, 2004), The Baden and Coțofeni cultures are, however, placed by some specialists in the Early Bronze Age (Vulpe, 2001a). Except of the Tiszapolgár culture that have emerged already during previous human impact and which have probably continued during this time period, only one site belonging to the Coțofeni culture was found in the Someş Valley (Vulpe 2001a; Iercoşan, 2002). The Cooper Age tribes are known for their ability to prepare copper tools (axes, weapons) as well as gold and pottery (Ursulescu et al., 2001; Vulpe 2001a). All these activities may have accounted for change in woodland composition.

Between 4200-4800 cal. yr BP, the palynological evidence from Preluca Tiganului shows a drastic reduction of the woodland diversity from Picea-Corylus with Quercus, Ulmus, and Tilia to one dominated by Fagus with Carpinus, Quercus, Alnus, and Betula (Fig. 3). At Steregoiu, 


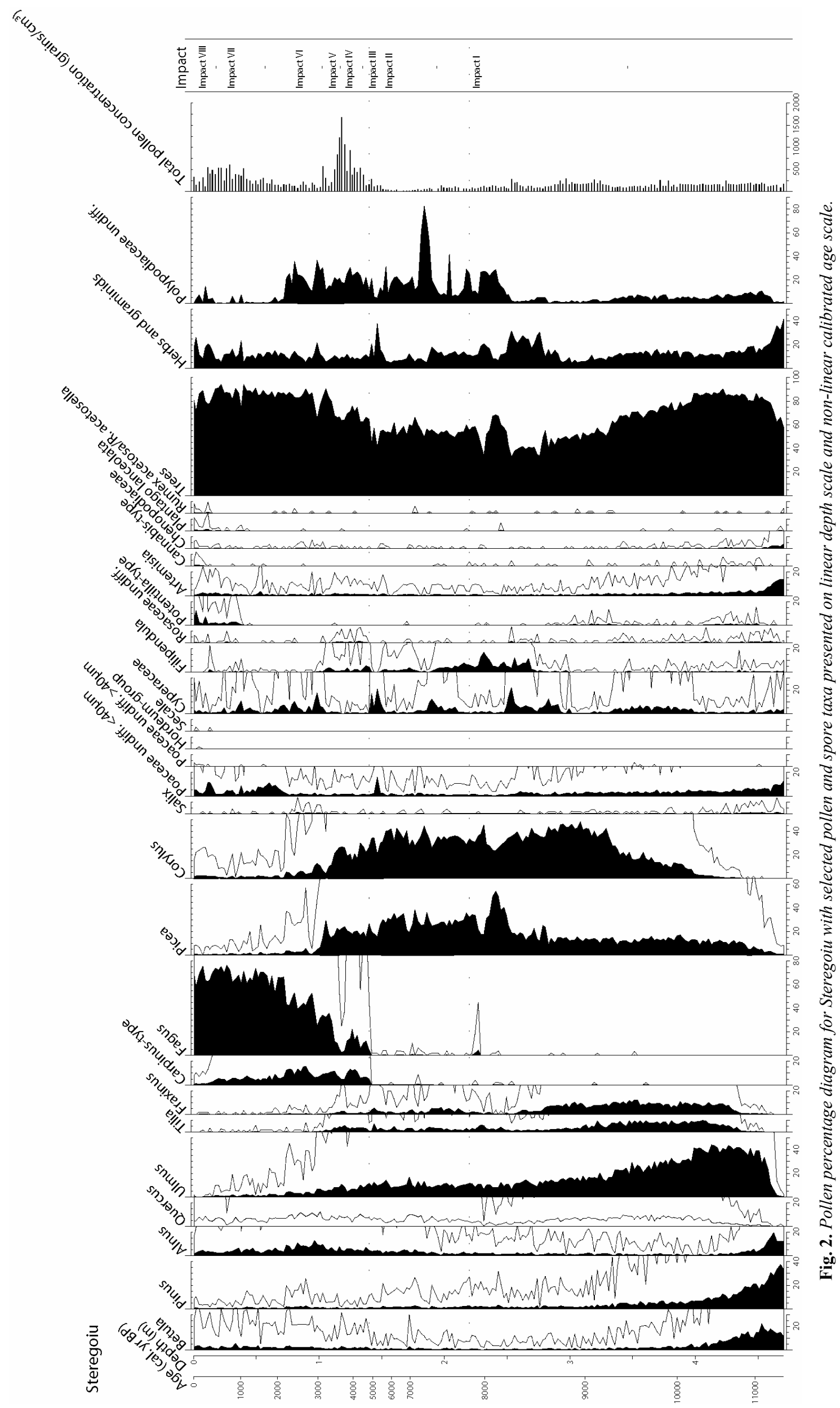




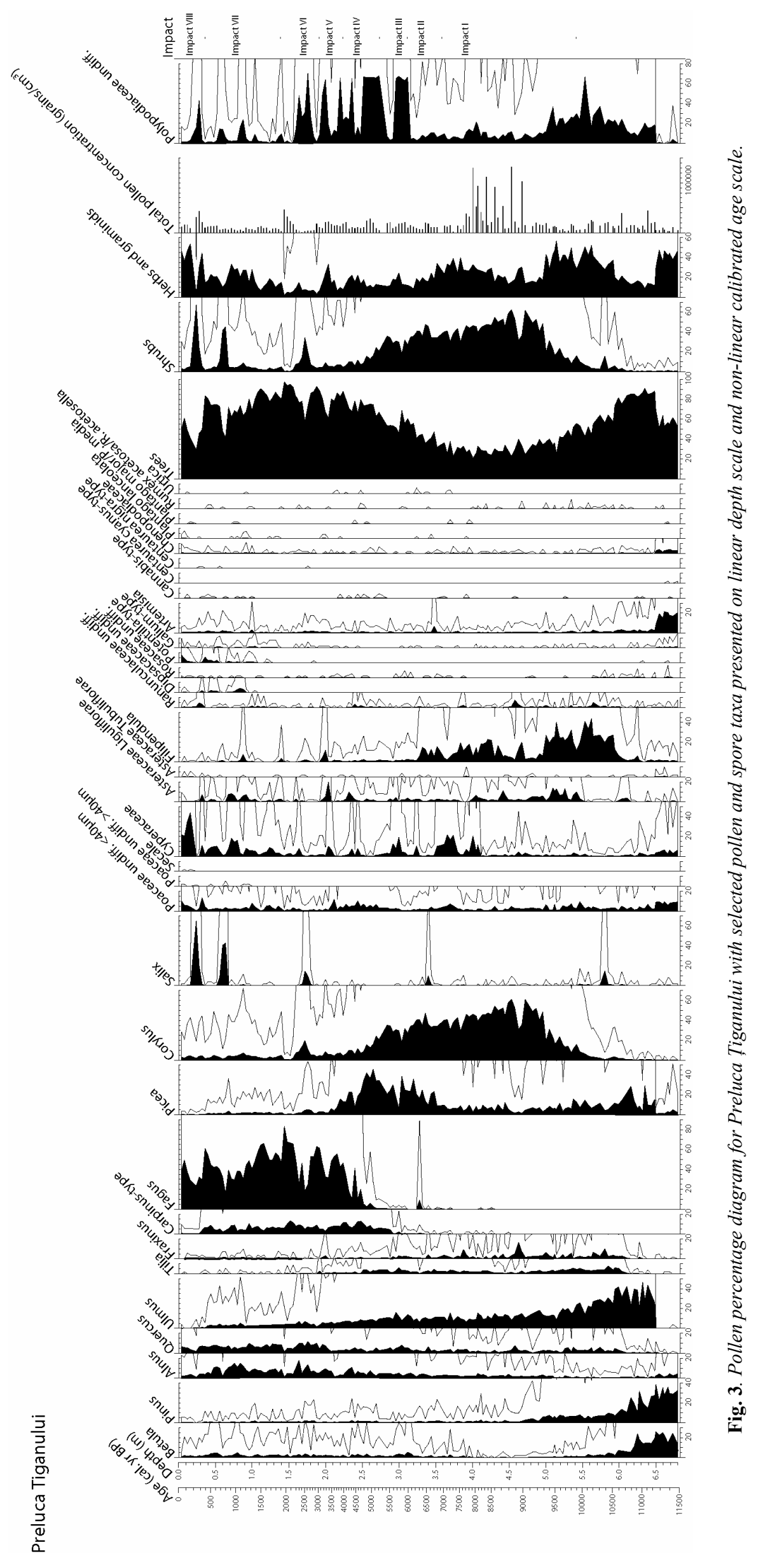



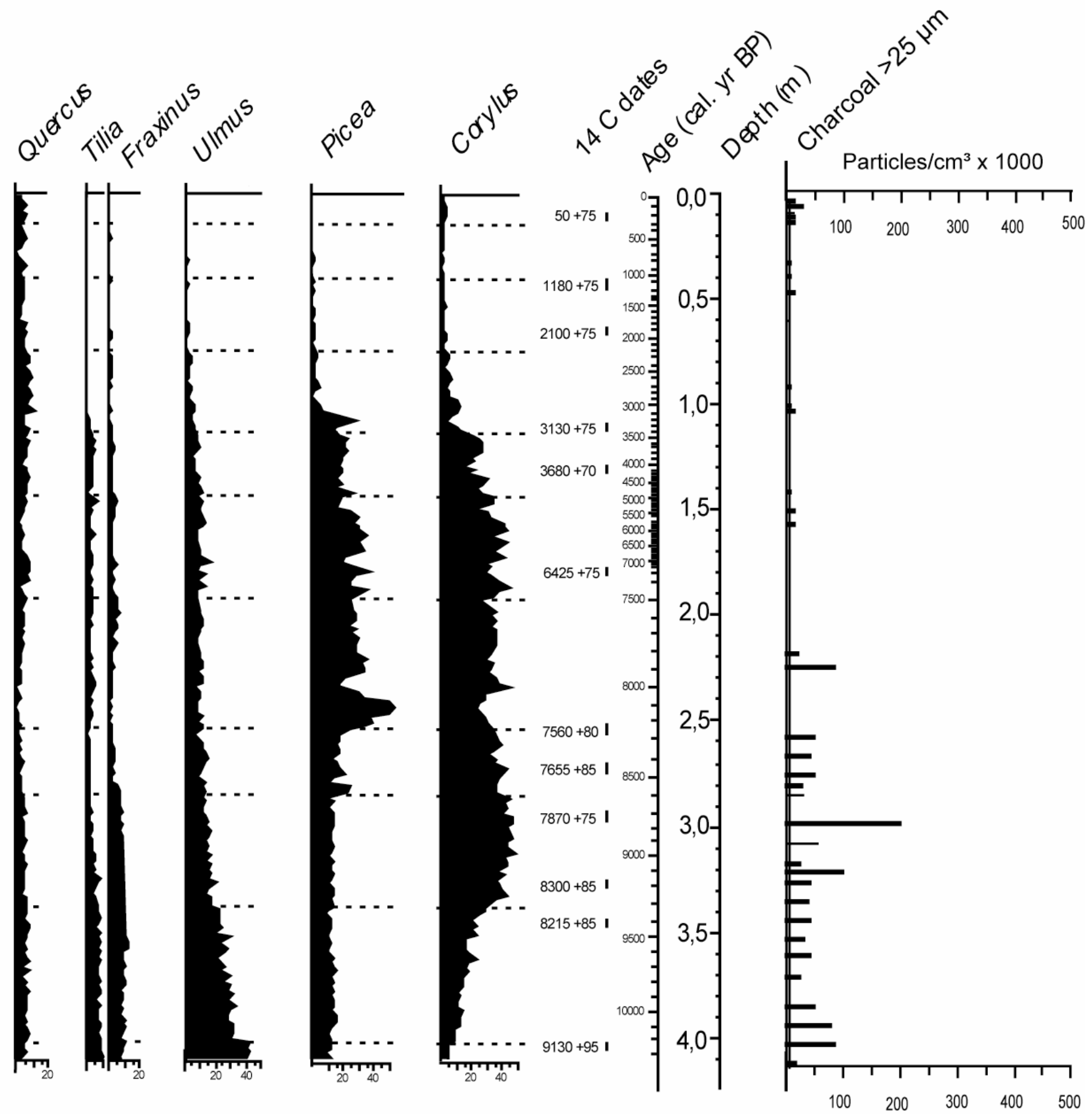

Fig. 4. Diagram showing micro-charcoal concentrations and selected tree pollen taxa percentages in the sequence from Steregoiu. The diagram is presented on linear depth scale and calibrated years are shown on non-linear timescale. The radiocarbon dates are also given to the left side of the calibrated timescale.

this reduction is less evident and is clearer observed slightly later, between 3500-4000 cal. yr BP (Fig. 2). The age discrepancy may be the result of hiatus, or to extremely compressed sediments that accumulated between 3500-5500 cal. yr BP and created problems of interpolation between dates at individual sites. The slight increase in some herbaceous pollen values (e.g. Artemisia, Chenopodiaceae, Rosaceae, Asteraceae Tubuliflorae, Ranunculaceae, Urtica, Rumex acetosa/acetosella), particularly at Preluca Tiganului, may reflect extension of meadows and pastureland in these openings. Evidence for a more openground also comes from ferns (Human IV, Table 1). Archaeological data from north-western Romania and northeastern Hungary show the emergence of the Early and the Middle Bronze Age cultures (Bader, 1978; Willis et al.,
1998; Vulpe, 2001a; Sümegy, 2004). This period is regarded as one with intensive transformation of the Hungarian environment following after the Early Neolithic. The Oaş Depression is lacking of archaeological records of the Early Bronze Age, but there is one wooded fort of the Middle Bronze Age located at Boineşti - Bélavára and linked to the Suciu de Sus culture (Bader, 1978). In contrast, the archaeological sites of the Middle Bronze Age are well represented in the Someş Valley (Vulpe, 2001a; Bader, 1978).

Two episodes of vegetation change are detected between 2200-3400 cal. yr BP. First, between 3200-3400 cal. yr BP, was the maximum extension of Fagus woodland with some Carpinus and Quercus, along with the final decline of Tilia, and with a gradual reduction of Ulmus, Picea, and Corlyus 
(Human impact V, Table 1). During this phase, the opportunistic species (Betula, Alnus, Fraxinus, and Pinus) show positive correlation with micro-charcoal concentration (Figs. 2-4). Secondly, between 2200-2800 cal. yr BP, Fagus decline and was replaced by Carpinus, Quercus, Corylus, Salix, Pinus, Betula, and Alnus (Human impact VI, Table 1). No increase in herbaceous pollen was noted pointing to a rapid replacement of forest lost by tree taxa by the opportunistic species (Human impact V-VI, Table 1). Since herbaceous plants indicators of human disturbance were almost absent, these changes were attributed to the natural forest succession driven by the change to drier climatic conditions (Björkman et al., 2003; Feurdean, 2005a). Generally, Quercus is anthropogenic-favored taxa and produces more pollen in a less dense forest. It also expands in periods of increasing fire activity and warm and/or dry condition. Woodland clearance and anthropogenic-induced burning must have played a role in alteration of the woodlands structure, while a drier climate could have increased the fire susceptibility (Human impact V-VI, Table 1).

Table 1. Correlation between archaeological records from the Oaş Depression and the Lower Someş Valley and human impact phases inferred from pollen diagram from the Gutâiului Mountains. The chronology is given in cal. yr BP.

\begin{tabular}{|c|c|c|c|c|c|}
\hline $\begin{array}{l}\text { Human } \\
\text { impact }\end{array}$ & $\begin{array}{l}\text { Preluca } \\
\text { Tiganului }\end{array}$ & Steregoiu & $\begin{array}{c}\text { Archaeological } \\
\text { periods and cultures }\end{array}$ & Archaeological sites & Description of the vegetation changes \\
\hline VIII & $300-0$ & $300-0$ & Modern times & & $\begin{array}{l}\text { High value of micro-charcoal concentration } \\
\text { Decline in forest diversity. Marked increase in Poaceae }>40 \mu \mathrm{m} \text {, first occurrence of Hordeum- } \\
\text { group, Secale, and Juglans-type }\end{array}$ \\
\hline VII & $1500-500$ & $1500-500$ & Early to Late Migration Age & $\begin{array}{l}\text { Lazuri, Culciu Mare, Culciu Mic, } \\
\text { Livada, Turulung-Vii }\end{array}$ & $\begin{array}{l}\text { Increase in charcoal concentration } \\
\text { Decrease in Fagus, increase in Betula, Salix, and Alnus } \\
\text { Increase in Artemisia, Chenopodiaceae, Rosaceae, Asteraceae, Ranunculaceae, Urtica, Rumex } \\
\text { acetosa/acetosella, Dipsacaceae, Potentila-type } \\
\text { First occurrence of Poaceae }>40 \mu \mathrm{m}=\text { Cerealia } \\
\text { Increase in infesting weeds Centaurea nigra-type and Plantago lanceolata } \\
\text { Small increase in Cannabis-type }\end{array}$ \\
\hline VI & $2800-2200$ & $2800-2200$ & $\begin{array}{l}\text { Iron Age: Middle to Late Hallstatt, } \\
\text { Middle La Tène } \\
\text { Iron Age: Early Hallstatt - Gáva II }\end{array}$ & $\begin{array}{l}\text { Călineşti Oaş - Hurca, Apa, Culciu } \\
\text { Mare, Lazuri, Satu Mare }\end{array}$ & $\begin{array}{l}\text { Decrease in Fagus and Carpinus } \\
\text { Increase in Pinus, Betula, Quercus, Alnus, Corylus, and Salix }\end{array}$ \\
\hline $\mathbf{v}$ & $3300-3200$ & $3400-3300$ & Late Bronze Age: Suciu de Sus & $\begin{array}{l}\text { Boinești (3 sites), Remetea Oaşului (2 } \\
\text { sites), Vama, Turt, Turulung Vii, } \\
\text { Culciu Mare (2 sites), Culciu Mic, } \\
\text { Medieşu Aurit (3 sites), Iojib, Lazuri (2 } \\
\text { sites), Noroieni, Odoreu (2 sites); } \\
\text { Livada, Valea Vinului, Adrian (2 sites) }\end{array}$ & $\begin{array}{l}\text { Increase in micro-charcoal concentration } \\
\text { Maximum extension of Fagus with some Carpinus and Quercus, decrease in Tilia, Ulmus, Picea, } \\
\text { and Corlyus; increase in Betula, Alnus, Fraxinus, and Pinus }\end{array}$ \\
\hline IV & $4800-4200$ & $4000-3500$ & $\begin{array}{l}\text { Middle Bronze Age: Otomani, Suciu } \\
\text { de Sus(Steregoiu) } \\
\text { Early Bronze Age (Preluca } \\
\text { Țiganului) }\end{array}$ & $\begin{array}{l}\text { Boineşti - Bélavára, Culciu Mic, } \\
\text { Medieşu Aurit } \\
?\end{array}$ & $\begin{array}{l}\text { Abrupt decrease of the woodland diversity from Picea-Corylus with Quercus, Ulmus, and Tilia to } \\
\text { one dominated by Fagus with Carpinus, Quercus, Alnus, and Betula } \\
\text { Small increase in Artemisia, Chenopodiaceae, Rosaceae, Asteraceae, Ranunculaceae, Urtica, } \\
\text { Rumex acetosa/acetosella }\end{array}$ \\
\hline III & $5750-5200$ & $5000 ?$ & $\begin{array}{l}\text { Late Cooper Age: Baden, Coțofeni } \\
\text { Early to Middle Cooper Age: final } \\
\text { Tiszapolgár, Bodrogkeresztúr }\end{array}$ & Apa, Seini, Dumbrava (Tiszapolgár) & $\begin{array}{l}\text { Small rise in micro-charcoal concentration } \\
\text { Small decline in Quercus, Ulmus, Tilia, and Fraxinus } \\
\text { Increase in Betula, Alnus, Picea, and Corylus } \\
\text { High values of Polypodiaceae undiff. }\end{array}$ \\
\hline II & $6600-6000$ & $6600 ?$ & $\begin{array}{l}\text { Early Cooper Age: Tiszapolgár } \\
\text { Late Neolithic:Tisza, Herpály }\end{array}$ & $\begin{array}{l}\text { Apa, Dumbrava, Seini } \\
\text { Apa, Dumbrava, Oraşu Nou }\end{array}$ & $\begin{array}{l}\text { Distinct peak in Fagus, increase in Betula, Corylus, and Salix } \\
\text { Increase in Artemisia, Rosaceae, Urtica, and Asteraceae }\end{array}$ \\
\hline I & $7900-7500$ & $7900-7800$ & $\begin{array}{l}\text { Early Neolithic: Starčevo-Criş/ } \\
\text { Körös }\end{array}$ & $\begin{array}{l}\text { Călineşti Oaş, Remetea Oaşului (?), } \\
\text { Medieşu Aurit }\end{array}$ & $\begin{array}{l}\text { Increase in micro-charcoal concentration } \\
\text { Small increase in Betula and Fraxinus. Small increase in Plantago lanceolata, Artemisia, Rumex } \\
\text { acetosa/acetosella, Sinapis-type, and Rosaceae }\end{array}$ \\
\hline
\end{tabular}

Numerous archaeological sites that belong to the Late Bronze Age Suciu de Sus culture were found in the Oaş Depression and along the Someş Valley (Bader, 1978; Marta, in prep) coinciding to the human impact V. Natural woodlands in these areas may have been affected by the increase in settlement density, and by the economical activities (woods for metallurgy, material needed for building).

The beginning of the Human Impact VI (at ca. 2800 cal. yr BP) probably coincided with the final phase of the Early Hallstatt fortification found at Călineşti Oaş - Hurca (Marta, 2001) and attributed to the second phase of the Gáva culture (Iron Age). Several other sites in the Someş Valley can also be attributed to the second phase of the Gáva culture (Marta, in prep), but thereafter the archaeological finds are lacking. However, the scarce archaeological information is common fact for Transylvania. This is explained by the type of economy (which at this time was based on animal husbandry) and by the high mobility of population of the Late Hallstatt and the beginning of the La Tène period (Vulpe, 2001b).

The charcoal concentrations display relatively higher values between 500-1500 cal. yr BP (Fig. 4). At Preluca Tiganului, Fagus pollen values regressed and values for Betula, Salix, and Alnus increased between 500-1300 cal. yr BP (Fig. 3). The marked increased in the pollen of herbaceous plant provides evidence for the expansion of the grasses and herbs in the proximity of the basins (Figs. 2, 3). The good correlation between micro-charcoal concentrations, the reduction in forest diversity, and the expansion of wooded pioneer species, in parallel with the rise of wild anthropogenic indicators, suggest that fire was also used in land management (Human impact VII, Table 1). Most of the obtained lands in the woodland were used for grazing, which also prevented re-growth of shoots and recovery of the previous diverse woodland. The archaeological data suggests a strong influence of the Early Slaves along the Someş Valley (Stanciu, 1999). In the Oaş Depression the archaeological information is absent until the Middle Age (beginning of the last millennium), when written sources point to the emergence of numerous villages in the Oaş Depression (Velcea, 1964).

During the last 300 years, marked changes in forest composition are reflected in the disappearance of almost all other tree species from the Fagus forests, except for Quercus (Figs. 2, 3). During the last two centuries, the intensive exploitation of the woodlands has made irreversible transformation in the lowlands that were transformed into open settlement areas. The woodlands were intense cleared and these woods were used for different economic activities (Human impact VIII, Table 1). Increasing fire frequency, probably also of anthropogenic origin is indicated by high values of charcoal concentration (Fig. 4). The woodlands (mixed oak) below $500 \mathrm{~m}$ a.s.1., 
were opened up, but large parts of the forest above this elevation (beech dominated) are still preserved.

\section{Grazing and pastureland}

Another sign of human influences on the vegetation is the increase in the pollen of pasture plants (Behre, 1981, 1988). The pollen of these plants (e. g. Poaceae undiff. $<40$ $\mu \mathrm{m}$, Plantago major, $P$. media, Rumex acetosa/R. acetosella, Chenopodiaceae, Artemisia, Asteraceae Tubuliflorae, Asteraceae Liguliflorae, Urtica, Centaurea cyanus-type, Ranunculaceae, and Cyperaceae) are documented from the beginning of the Holocene in the pollen diagrams from Steregoiu and Preluca Tiganului. These, might also been derive from natural fen or wild growing herb communities around the sites (Figs. 2, 3). Except for a peak in Artemisia pollen, evident around 6600 cal. yr BP (Human impact II), pollen percentages of Poaceae undiff. $<40 \mu \mathrm{m}$, Plantago lanceolata, Rumex acetosa/R. acetosella, and Cannabis-typ and of nitrophilous and ruderal plants (Artemisia, Chenopodiaceae, and Urtica) stayed low until about 1500 cal. yr BP. From this time onwards (Human impact VII) and more clearly during the last 300 years (Human impact VIII), the pollen of herbs mentioned above along with Potentilla-type, Rosaceae, and Dipsacaceae undiff. show a marked rise indicating that grazing and forest grazing pressure became more intense.

\section{Agriculture}

Agriculture is reflected in the pollen diagrams by the presence of pollen of cultivated plants (particularly cereals), weeds, and ruderal species. A few pollen grains of Poaceae $>40 \mu \mathrm{m}$, which may be derived from cereals such as Triticum, Hordeum, and Avena were first recorded around 1500 cal. yr BP (Figs. 2, 3). Simultaneously, the pollen grains of infesting weeds (Centaurea nigra-type) and pollen associated with fallow lands (Plantago lanceolata) were found, thus confirming the practise of agriculture (Human impact VII). In the last 300 years (Human impact VIII), Poaceae $>40 \mu \mathrm{m}$ pollen became increasingly common, along with the appearance of a few pollen grains from Hordeumgroup and Secale (Figs. 2, 3). Nevertheless, as suggested by Björkman et al. (2003), the pollen grains were probably originated from cultivated lands situated at low altitude in the Oaş Depression and do not indicate the proximity of arable fields to the investigated sites. The characteristics of the surroundings of the study sites make them less suitable for settlements and agriculture. The palaeoecological data agrees with the archaeological evidence from the Oaş Depression and the Someş Valley, which suggest an increased in population density stating with the Late Migration Age (Velcea, 1964; Stanciu, 1999).

Other pollen types of cultivated plants found in our diagrams were Cannabis-type and Juglans-type, indicating that Cannabis sativa and Juglans regia may have been grown in the Oaş Depression. Cannabis pollen grains could also be derived from wild plants e.g. Humulus lupulus or Cannabis sativa ssp. spontana. Both species occur spontaneously in Romania in damp scrubland, wet forest and as a weed (Păun et al., 1980). Most likely Cannabis (hemp) and Humulus (hop) grew wild during the Lateglacial and the whole Holocene in the Gutâiului Mountains. During the last 1500 years hemp pollen values increased slightly, which may indicate that Cannabis sativa started to be cultivated in the Oaş Depression, and was used for fibres and for medical purpose. The presence of hemp seeds in archaeological sites in Romania is dated to 1250 cal. yr BP (Cârciumaru, 1996). High values of Cannabis-type pollen in the last 1000 years in Hungary were attributed to cultivation for rope production (Willis, 1997).

\section{CONCLUSIONS}

Pollen and charcoal record from the Gutâiului Mountains combined with archaeological evidence from the Oaş Depression, Someş Valley and north-eastern Hungary bring information about the time and scale of human influence on the vegetation.

The first sign of human impact could be considered the burning of woodlands to obtain fields for grazing, initiated around 7900 cal. yr BP. This agrees with the archaeological evidence from the Oaş Depression that indicates the emergence of the Early Neolithic culture. The human activities recorded between 7900-1500 cal. yr BP imply some woodland clearance. Due to the small scale of clearance and fire, the forest regenerated, but the vegetation assemblages have also included opportunistic species (Betula, Alnus, Corylus, and Fraxinus). During the last 1500 years and more intensely during the last 300 years, an abrupt reduction in forest density and diversity is recorded. The burnings and grazing pressure became stronger, as the forest could not regenerate.

Evidence for the expansion of pasturelands and meadows were found from ca. $1500 \mathrm{cal}$. yr BP onwards with intensification during the last 300 years.

The sign of cultivation is first recorded around $1500 \mathrm{cal}$. yr BP with the appearance of Poaceae $>40 \mu \mathrm{m}$ pollen. During the last 300 years, the cultivation of cereals is documented by the occurrence of pollen of Secale, Hordeum group, and Juglans. Cannabis sativa may also have been cultivated. These grains, however, probably originated from fields from the Oaş Depression. The appearance of cultivated fields coincides with increased settlements in the Oaş Depression recorded at the beginning of the Middle Age

The low number of archaeological sites from the Oaş Depression is most probably the result of scarcity of the archaeological investigation; therefore further archaeological investigations are needed. This should, however, be combined with the palaeoecological records as they can provide an estimated scale of the human impact, and vegetation dynamics after disturbance.

Acknowledgements. We are grateful to Barbara Wohlfarth, Leif Björkman and Ann-Marie Robertsson for comments on a very early draft of this manuscript. Liviu Marta is thanks for offering us new data concerning the Late Bronze Age and the Early Hallstatt periods, and Joe Kearns for the English correction. Spasimir Tonkov and one anonymous reviewer are greatly acknowledged for their suggestions that improved the manuscript.

\section{R E F E R E N C E S}

Ammann, B. 1989, Late-Quaternary palynology at Lobsigensee. Regional vegetation history and local lake development. Dissertationes Botanicae. J. Cramer BerlinStuttgart. 
Andriç, M., Willis, K.J. 2003, The phytogeographical regions of Slovenia: a consequence of natural environmental variation or prehistorc human activity? Journal of Ecology, 91: 807-821.

Bader, T. 1978, Epoca bronzului în nord-vestul Transilvaniei. Cultura tracică şi pretracică. Ed. Ştiințifică şi Enciclopedică, Bucureşti, 248 pp.

Behre, K.E. 1981, The interpretation of anthropogenic indicators in pollen diagrams. Pollen et Spores, 213: 225-245.

Behre, K.E. 1988, The role of Man in European vegetation history. In Vegetation History (Huntley, B. \& Webb, T. III., Eds.), Dordrecht: Kluwer Academic Publishers, 633-672.

Berglund, B.E. 2000, The Ystad Project - a case study for multidisciplinary research on long-term human impact. PAGES Newsletter, 8: 6-7.

Berglund, B.E. 2003, Human impact and climatic changessynchronous events and a causal link? Quaternary International, 105: 7-12.

Birks, H.J.B. 2003, Late-Quaternary biotic changes in terrestrial and lacustrine environments, with particular reference to north-western Europe. In Handbook of Holocene Palaeoecology and Palaeohydrology (Berglund, B., Ed.), The Blackburn Press, 41-47.

Bitiri, M. 1972, Paleoliticul în Țara Oaşului -studiu arheologic. Bucureşti, Centrul de informare şi documentare în ştiințele sociale şi politice, $196 \mathrm{pp}$.

Björkman, L., Feurdean, A., Cinthio, K., Wohlfarth, B., Possnert, G. 2002, Lateglacial and early Holocene vegetation development in the Gutaiului Mountains, NW Romania. Quaternary Science Reviews, 21: 1039-1059.

Björkman, L., Feurdean, A., Wohlfarth, B. 2003, Lateglacial and Holocene forest dynamics at Steregoiu in the Gutâiului Mountains, NW Romania. Review of Palaeobotany and Palynology, 124: 79-111.

Bradshaw, R.H.W. 1991, The spatial scale in the pollen record. In Modelling ecological change (Harris, D.R., Thomas, K.D., Eds.), London: Institute of Archaeology Publications, 41-53.

Bronk Ramsey, C. 1995, Radiocarbon calibration and analysis of stratigraphy: the OxCal program. Radiocarbon, 37: 425-430.

Cârciumaru, M. 1996, Paleoetnobotanica. Studii în preistoria şi protoistoria României. Ed. Glasul Bucovinei, Helios: Iaşi, $201 \mathrm{pp}$.

Clark, J.C. 1988, Particle motion and theory of charcoal analysis: source area, transport, deposition and sampling. Quaternary Research, 30: 67-80.

Ciugudean, H. 2000, Eneoliticul final în Transilvania şi Banat: cultura Coțofeni. Ed. Mirton, Timişoara, pp.284.

Feurdean, A., Björkman, L., Wohlfarth, B. 2001, A paleoecological reconstruction of the Late Glacial and Holocene based on multidisciplinary studies at Steregoiu site (Gutai Mts., NW Romania). Studia Universitatis Babeş-Bolyai, Geologia, XLVI (2), 125-140.

Feurdean, A. 2004, Palaeoenvironment in Romania during last 15,000 years. PhD thesis in Quaternary Geology, 3, Department of Physical Geography and Quaternary Geology, Stockholm University, Sweden, $51 \mathrm{pp}$.

Feurdean, A., Bennike, O. 2004, Late Quaternary palaeoecological and paleoclimatological reconstruction in the Gutaiului Mountains, NW Romania. Journal of Quaternary Science, 19: 809-827.
Feurdean, A. 2005a, Holocene forest dynamics in northwestern Romania. The Holocene, 15: 435-446.

Feurdean, A. 2005b, Tracking Lateglacial and early Holocene environmental changes $-\mathrm{a}$ paleolimnological study of sediment at Preluca Triganului, NW Romania. Studia Universitatis Babeş-Bolyai, Geologia, 50: 3-11.

Gardner, A.R. 2002, Neolithic to Copper Age woodland impacts in northeast Hungary? Evidence from the pollen and sediment chemistry records. The Holocene, 12: 541-533.

Grimm, E.C. 1992, Tilia and Tilia-graph: Pollen spreadsheet and graphics programs. Programs and Abstracts, 8th International Palynological Congress, Aix-en-Provence, September 6-12, pp. 56.

Horvath, F. \& Hertelendi, E. 1994, Contribution to the ${ }^{14} \mathrm{C}$ based absolute chronology of the Early and Middle Neolithic Tisza region. In A Nyiregyházi Jósa András Múzeum Évkönyve, XXXVI: 111-133.

Iercoşan, N. 2002, Cultura Tiszapolgár în vestul României, Ed. Muzeului Sătmărean, Nereamia Napocae, ClujNapoca, 385 pp.

Istvan, D., Popescu, S. \& Pop I. 1990, Munții Gutâi. Ed. Sport-Turism, Bucureşti, 149 pp.

Iversen, J. 1949, The influence of prehistoric man on vegetation. Danmarks Geologiske Undersøgelse, 3: 1-25.

Iversen, J. 1960, Problems of the early postglacial forest in Denmark. Danmarks. Geologiske Undersøgelse, 4 (3): $1-32$.

Jacobson, G.L. \& Bradshaw, R.H.W. 1981, The selection of sites for paleovegetational studies. Quat. Res., 16: 80-96.

Lupşa, V. 1980, Evoluția postglaciară a ecosistemelor forestiere din "Țara Oaşului" (Jud. Satu Mare). Contribuții Botanice, 5: 63-68.

Marta, L. 2001, Călineşti Oaş-Hurca. Cronica cercetărilor arheologice din România, campania 2000, cIMeC, Bucureşti, 59-60.

Maxim, Z. 1999, Neo-eneoliticul din Transilvania. Date arheologice şi matematico-statistice. Cluj-Napoca, $314 \mathrm{pp}$.

Németi, J. \& Astaloş C. 2001, Călineşti-Oaş - Dâmbul Sfintei Mării. Cronica cercetărilor arheologice din România, campania 2000, cIMeC, București, 60-61.

Păun, M., Turenschi, E., Ifteni, L., Ciocarlan, V., Moldovan, I. 1980, Botanica. Ed. Didactică şi Pedagogică, Bucureşti.

Patterson, W.A., Edwards, K.J. \& Maguire, D.J. 1987, Microscopic charcoal as a fossil indicator of fire. Quaternary Science Review, 6: 3-23.

Potushniak, M. 2004, Data to the question of the Starčevo / Körös Culture dwellings in the Upper Tisza Region. $A$ Nyiregyházi Jósa András Múzeum Évkönyve, XLVI: 53-69.

Ralska-Jasiewiczowa, M., Nalepka, D. \& Goslar, T. 2003, Some problems of forest transformation at the transition to the oligocratic/Homo sapiens phase of the Holocene interglacial in northern lowlands of central Europe. Vegetation History and Archaeobotany, 12: 233-247.

Rösch, M. 1998, The history of crops and crop weeds in south-western Germany from the Neolithic period to modern times, as shown by archaeobotanical evidence. Vegetation History and Archaeobotany, 7: 109-125.

Sümegi, P. 2004, The results of paleoenvironmental reconstructions and comparative geoarchaeological analysis for the examined area. In The geohistory of 
Bátorliget marshland (Sümegy, P. \& Gulyás, S., Eds,), Archaeolingua, Budapest, 301-348.

Stockmarr, J. 1971, Tablets with spores used in absolute pollen analysis. Pollen et Spores, 13: 615-621.

Stuiver, M., Reimer, P.J., Bard, E., Beck, J.W., Burr, G.S., Hughen, K.A., Kromer, B., McCormac, G., van der Plicht, J., Spurk, M. 1998, INTCAL98 Radiocarbon age calibration, 24,000-0 cal BP. Radiocarbon, 40: 1041-1083.

Stanciu, I. 1999, Așezarea slavă timpurie de la Lazuri "Lubi Tag" jud Satu Mare (Cercetările arheologice din anii 1977, 1993-1995). Contribuții la cunoaşterea secolelor VI-VII în zona Tisei Superioare. Satu Mare Studii şi Comunicări, XV-XVI: 115-266.

Sugita, S., 1994, Pollen representation of vegetation in Quaternary sediments: theory and method in patch vegetation. Journal of Ecology, 82: 881-897.

Ursulescu, N., Petrescu-Dîmbovița, M. \& Monah, D. 2001, Neo-eneoliticul. In Istoria românilor, vol. I, Moştenirea timpurilor îndepartate (Petrescu-Dîmbovița, M. \& Vulpe, A., Eds.), Bucureşti, Ed. Enciclopedică, 111-209.

Velcea, I. 1964, Țara Oaşului. Studiu de geografie fizică şi economică. Ed. Academiei R.P.R., Bucureşti, 168 pp.

Vulpe, A., 2001a, Epoca metalelor. In Istoria românilor, vol. I, Moştenirea timpurilor îndepărtate (PetrescuDîmbovița, M. \& Vulpe, A., Eds.), Ed. Enciclopedică, Bucureşti, 211-395.
Vulpe, A., 2001b, Istoria si civilizaţia spaţiului carpatodunărean între mijlocul secolului al VII-lea şi începutul secolului al III-lea a.Chr. In Istoria românilor, vol. I, Moştenirea timpurilor îndepărtate (Petrescu-Dîmbovița, M. \& Vulpe, A., Eds.), Ed. Enciclopedică, Bucureşti, 451-500.

Willis, K.J. 1994, The vegetational history of the Balkans. Quaternary Science Reviews, 13: 769-788.

Willis, K.J., Bennett, K.D. 1994, The Neolithic transitionfact or fiction? Palaeoecological evidence from the Balkans. The Holocene 4: 326-330.

Willis, K.J. 1997, The impact of early agriculture upon the Hungarian landscape. In Landscapes in flux: Central and Eastern Europe in Antiquity (Chapman, J. \& Dolukhanov, P., Eds.), Oxbow Books Ltd, 193-209.

Willis, K.J., Sumegi, P., Braun, M. Bennett, K.D., Toth, A. 1998, Prehistoric land degradation in Hungary: who, how and why? Antiquity, 72: 101-113.

Whitlock, C. \& Larsen, C.P.S. 2001, Charcoal as a Fire Proxy. In Tracking Environmental Change Using Lake Sediments (Vol. II) (Smol, J.P., Birks, H.J.B. \& Last, W.M., Eds.), Dordrecht: Kluwer Acad. Publishers, 75-97.

Wohlfarth, B., Hannon, G., Feurdean, A., Ghergari, L., Onac, B.P., Possnert, G. 2001, Reconstruction of climatic and environmental changes in NW Romania during the early part of the last deglaciation $(15,000-13,600$ cal years BP). Quaternary Science Reviews, 20: 1897-1914. 